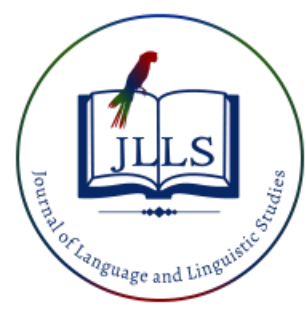

Available online at www.jlls.org

JOURNAL OF LANGUAGE AND LINGUISTIC STUDIES

ISSN: $1305-578 \mathrm{X}$

Journal of Language and Linguistic Studies, 16(4), 1698-1721; 2020

\title{
Investigating EFL speakers' gratitude strategies: Interlanguage pragmatics
}

\author{
Derya Bakırc1 $^{a 1}$ (iD), Ali Şükrü Özbay ${ }^{\text {b* }}$ (D) \\ ${ }^{a}$ Düzköy Anatolian High School, Trabzon, Turkey \\ ${ }^{b}$ Karadeniz Technical University, Trabzon, Turkey
}

\begin{abstract}
APA Citation:
Bakırcı, D. \& Özbay, A. Ş. (2020). Investigating EFL speakers' gratitude strategies: Interlanguage pragmatics. Journal of Language and Linguistic Studies, 16(4), 1698-1721.

Submission Date:13/05/2020
\end{abstract}

Acceptance Date:31/082020

\begin{abstract}
Gratitude strategies used by EFL speakers have always been the focus of interest by researchers who observed the presence of pragmatic transfer strategies by which speakers express their gratitude. We have seen that several adapted versions of Discourse Completion Tasks (DCTs) by Eisenstein and Bodman (1986) are constructed based on the original version and largely applied to the participants from various backgrounds. A similar methodology is used in this study and we investigated the gratitude strategies of participants, including $80 \mathrm{EFL}$ learners in Turkey and 70 non-native European speakers of English at tertiary-level. We also interviewed with 44 Turkish speaking participants and used two sampling methodologies to identify the participants that could promote the data obtained from the DCTs. Our research entailed quantitative and qualitative data examined through content analysis. Primary findings indicated strong divergences and weak similarities between both speaker groups who resorted to the speech act of thanking compared to non-native European speakers who also differed in thanking strategies. Finally, we have been provided with valuable indications for the constituent parts of the language teaching that neglect the instructional side on the pragmatic use of language for gratitude and other speech acts.
\end{abstract}

C) 2020 JLLS and the Authors - Published by JLLS.

Keywords: Gratitude; speech act of thanking; thanking strategies

\section{Introduction}

The speech act of gratitude is one of the common acts in everyone's life. It is essential to understand and produce gratitude expressions for a "favor", "service", "invitation" and failure to do so may sound unkind. Being polite and maintaining a successful communication necessitates suitable expressions to a particular situation and the knowledge of when to perform the act. Even though expressing gratitude is essential for speakers, how this speech act is realized is culture specific. Therefore, to reveal the crosscultural varieties, we analysed Turkish speaking tertiary-level EFL learners and non-native European speakers of English data. The comparison further created the baseline data of the research with which the investigation focused on gender, proficiency and pragmatic transfer.

\footnotetext{
1 Corresponding author. Tel.

E-mail address:: ozbay@ktu.edu.tr
} 
Considering the fact that each speech situation requires the awareness of the expectations to be realized (Elwood, 2010), we also have aimed to find out the degree of competence for the use of gratitude expressions for tertiary-level EFL speakers compared to the non-native speakers of English. Having analysed the corresponding and diverging sides between Turkish and English-speaking participants of European countries for the use of the expressions of gratitude, we have examined whether there are gender and English proficiency level-based varieties in replying to a favor. Being a multifaceted one, the study aims first to uncover the efficacy of tertiary-level Turkish EFL learners as to expressing their gratitude in English. Secondly, it aims to shed light on whether there are any diversions among the Turkish EFL learners in their expressions of gratitude considering their proficiency level and gender. Thirdly, it aims to find out the possible variations between tertiary-level Turkish EFL learners and nonnative speakers of English from various locations throughout Europe.

Meiramova and Kulzhanova (2015) argued that EFL speakers generally face difficulties in replying for the favor, which may be due to the lack of intercultural communication. Pishghadam and Zarei (2011), who examined Iranian EFL learners' pragmatic competence, concluded that culture is a very important factor in expressing speech acts for gratitude expressions. Xiaoyu and Mun-Hong (2015, p.121) found out that L2 speakers may not be aware that expressions of gratitude are universal communicative acts that enable different speech acts in cross-cultural communication. Expressing gratitude emerges as one of the most common speech acts resulting in failure or undesirable outcome among EFL speakers. The failure lies in the fact that many EFL speakers may sound strange in their expression of gratitude. While a simple "thanks" may work in a given case for the speaker, it may not do so when you are faced with another gratitude situation and you need to complement the gratitude yet with other words other than "thanks" for the reasons entirely formal, informal or traditional. This is important because "... becoming an effective speaker of a new language not only involves learning new vocabulary in addition to rules of pronunciation and grammar but must also include the ability to use these linguistic resources in ways that are socially appropriate among speakers of the target language" (Wolfson, 1989, p. 219). On the other hand, there is an extensive body of research in the field of pragmatic competence of EFL learners focusing on both the general framework and the different aspects of it, such as refusing, requesting, thanking, and so on. Most of the problems that EFL learners face in intercultural communication resulted from the intercultural miscommunication, accompanied by linguistic transfer of first language (L1) rules or the use of target language by learners who use their native speech communities' sociocultural norms during the verbal or written interactions in a second language (Al Falasi, 2007; Wolfson, 1989).

The intercultural miscommunication mentioned above is caused by lack of pragmatic competence. According to Dogancay-Aktuna and Kamisli (1997), "even fairly advanced learners make pragmatic errors such that they fail to convey or understand the intended message because of lack of awareness of pragmatic rules governing the TL or due to the lack of linguistic proficiency to convey the necessary act" (p. 3). Bardovi-Harlig (1999; 1996) demonstrated that learners at a variety of levels of grammatical proficiency produced a wide range of different responses from native speakers during communicative acts to realize certain speech acts, which indicates the fact that even advanced level language learners suffer hardship in expressing gratitude efficiently in a target language (Eisenstein \& Bodman, 1986). Dogancay-Aktuna and Kamışlı (1997) also indicate that advanced Turkish learners who take grammarbased tests vary to a large extent from the standards of the target language and as a result, experience failure in the appropriate use of language in social contexts. Li, Suleiman and Sazalie (2015) searched for the pragmatic competence, pragmatic awareness and language production of Chinese EFL learners in their study. Buján Sánchez (2016), with a more specific focus, examines how competent Spanish students of EFL are concerning their strategies in expressing requests and apologies. While the pragmatic use of gratitude has attracted the attention of many researchers around the world (Choe \& 
Wang, 2015; Meiramova \& Kulzhanova, 2015; Elwood, 2010; Farnia \& Suleiman, 2009; Kashdan et al., 2009), there is a limited number of studies in the literature regarding Turkish EFL learners. In the Turkish context, Karatepe (2001) stated that the exposure to the authentic language for the learners of English is so limited that learners fail to express themselves using the language that is based on the cultural and social norms of the target language context. Hence, as a result of the lack in the pragmatic competences of the Turkish EFL learners, misunderstandings appear between interlocutors of the communicative situations and the messages neither reach the receiver as they are intended nor expected feedback returns. The research, for instance, conducted by Araz and Erdugan (2017) aim to create a scale to measure the use of expressions of gratitude among Turkish people. While Tulgar (2016) focuses on the role of pragmatic competence in foreign language education, Han and Tanriöver (2015) compiled the related literature under their study that scrutinizes the factors affecting pragmatic competence and Turkish EFL research context; Özdemir and Rezvani (2010) examine non-native speakers' speech acts of gratitude, who are Turkish and Iranian advanced level speakers of English, in an EFL context.

\subsection{Literature review}

Bialystok (1993, p. 43) gives three main constituents for being pragmatically competent: "1) the speaker's ability to use language for various purposes; 2) the hearer's ability to get past the language and find out the speaker's real communicative goal and 3) the command of the rules by which utterances strung together to set up discourse." Following the rising interest in second language (L2) learning, interlanguage pragmatics has also attracted the attention of many researchers; however, much of the research on interlanguage pragmatics has shed light neither on interlanguage nor acquisition and related studies mainly have concerned with L2 learners' performance of a specific speech act (Kasper, 1992). Moreover, these studies most generally could not reach beyond comparative acts by which three kinds of data examined: "(1) the baseline data from native speakers of the learners' native language, (2) the interlanguage data from the learners, (3) the target language baseline data from native speakers of the target language" (Kasper, 1992: 223). The reason why these studies own a contrastive nature has been placed in the field of cross-cultural pragmatics. Another reason was that the research in the field of interlanguage pragmatics has dominantly been applied to advanced non-native speakers due to the difficulty of tasks to be carried out (Ahn, 2007). Considering that acquisition is an ongoing process and has a cumulative nature, using advanced- level participants of a target language do not enable researchers to reveal how NNS have gained their pragmatic abilities and experiences through those developmental stages. Kasper (1992, p. 207) defined pragmatic transfer as "the influence exerted by learners' pragmatic knowledge of languages and cultures other than L2 on their comprehension, production and learning of L2 pragmatic information". She also categorized pragmatic transfer into two groups named positive pragmatic transfer and negative pragmatic transfer (1992). Positive transfer refers to shared conventions between a language learner's native tongue and target language, which enables language learners to transmit their messages across interlocutors with success. On the other hand, negative transfer appears when L1 pragmatic knowledge differs from L2 pragmatic knowledge and in which case, the communication process turns into a "pragmatic failure" as Thomas (1983) stated. Bodman and Eisenstein $(1988$, p. 1) explained the reasons behind these failures by stating that "...foreign or second language learners often assume that the expression of gratitude is universal and remain unaware of significant differences in its cross-cultural realization". Thereby, it appears that foreign language learners commonly tend to transfer their pragmatically accustomed speech behaviors in L1 to a target language. Lamb (2005), at this stage, argued that "sometimes there are expectations, and if we are not prepared for some responses or attitudes,... we may tend to interpret things in a different way than it was intended by the sender (p. 231)". 
Thomas (1983, p. 97) stated that "while grammatical error may reveal a speaker to be a less than proficient language-user, pragmatic failure reflects badly on him/her as a person". Therefore, the appropriate performance of language learners related to speech acts in target language conventions is essential for successful communication and the desired perception by intervening speakers. Eisenstein and Bodman (1986) described gratitude expressions as the following:

"An illocutionary act performed by a speaker which is based on a past act performed by the hearer. This past act benefits the speaker and the speaker believes it to have benefited him or her. The speaker feels grateful or appreciative and makes a statement which counts as an expression of gratitude (p. 67)."

While Searle (1969, p.67) classifies thanking as an expressive illocutionary act, Brown and Levinson (1987) classified thanking as a face-threatening act considering that the speaker feels a kind of debt to the favor giver. Intachakra (2004) opposed the idea of Brown and Levinson, and stated that if it is performed successfully, expressions of gratitude will please the faces of both speakers and hearers; yet unsuccessful attempts to use it may emerge a sense of disrespect. Coulmas (1981) emphasized another factor affecting the use of thanking as the following:

"The social relation of the participants and the inherent properties of the object of gratitude work together to determine the degree of gratefulness that should be expressed in a given situation. Differences in this respect are obviously subject to cultural variation (p. 75)".

For instance, Hymes (1972) pointed out that 'thank you' varies in British and American English. While it is widely used as a formulaic expression of gratitude in American English, the British prefer it as a more formal marker. Besides, Chang (2008) investigated the perception and production of Chinese EFL learners and English speakers regarding expressions of gratitude through a DCT and found that social status, the degree of imposition, and language proficiency were influential in the responses of the speakers.

\subsection{Research questions}

The questions sought in the research are as follows:

1- What are the strategies used by tertiary-level Turkish-speaking EFL learners while performing the speech act of expressing gratitude?

2- How do Turkish speaking EFL learners at tertiary-level and non-native European speakers of English differ in their use of expressions of gratitude?

3- Is there any difference between the male and female participants in terms of expressing their gratitude in both Turkish and English discourses?

4- Is there any significant improvement in the way of expressing their gratitude as the proficiency level of the learners increase?

\section{Method}


We have combined computer-based and quantitative and qualitative analysis techniques. The instruments consisted of a Discourse Completion Task (DCT) and a semi-structured interview. The original DCT paper was adopted from Einstein and Bodman's version (1986) and modified for Turkish speaking EFL learners and non-native speakers of English studying in various universities in Europe

Table 1. The Methodology of the Study

\begin{tabular}{|c|c|}
\hline $\begin{array}{l}\text { Research } \\
\text { Method }\end{array}$ & Exploratory Mixed Methods Paradigm (Numeric, Descriptive and Holistic ) \\
\hline The Setting & Mainly a technical university in Turkey; partly universities in European countries \\
\hline \multirow{2}{*}{$\begin{array}{l}\text { The } \\
\text { Participants }\end{array}$} & From Turkey: eighty students (40 first years and 40 second years) \\
\hline & From Europe: seventy students \\
\hline \multirow{2}{*}{ Data Collection } & $\begin{array}{l}\text { 1.DCTs: in Turkish (with eighty Turkish speaking participants); in English (with } \\
\text { eighty Turkish speaking participants and seventy non-native speakers of English in } \\
\text { Europe) }\end{array}$ \\
\hline & $\begin{array}{l}\text { 2. Semi-structured Interviews: with forty-four Turkish students in total (twenty-one } \\
\text { from first years and twenty-three from second years) }\end{array}$ \\
\hline \multirow{2}{*}{ Piloting } & The DCTs in Turkish and English were piloted with a group of Turkish students. \\
\hline & $\begin{array}{l}\text { The semi-structured interviews were also piloted with the same group of Turkish } \\
\text { students. }\end{array}$ \\
\hline \multirow{6}{*}{ Data Analysis } & 1. Disassembling DCTs' Data: attaining codes to the data \\
\hline & 2. Reassembling DCTs' Data: combining under categories \\
\hline & 3. DCTs were analysed via SPSS. \\
\hline & 4. Disassembling Interview Data: attaining codes to the data \\
\hline & 5. Reassembling Interview Data: combining under categories \\
\hline & 6. Semi-structured interviews were analysed descriptively. \\
\hline
\end{tabular}

\subsection{The Participants and the Setting}

The total population of the study is 150 tertiary-level students categorized basically into two groups: 80 native speakers of Turkish and 70 non-native speakers of English who reside in various European countries. Both sample groups were selected on a convenient sampling methodology. The demographic information provided below demonstrates only one group of individuals participating in the study.

Table 2. Demographic Information of Turkish Speaking Participants (Subjects) 


\begin{tabular}{llll}
\hline \multirow{2}{*}{ Gender } & Variables & Number & $\%$ \\
\hline \multirow{2}{*}{ Year } & Female & 54 & 67.5 \\
\cline { 2 - 4 } & Male & 26 & 32.5 \\
\hline \multirow{4}{*}{ Age } & $1^{\text {st }}$ Year & 40 & 50 \\
\cline { 2 - 4 } & $2^{\text {nd }}$ Year & 40 & 50 \\
\hline \multirow{5}{*}{ English Proficiency } & $18-19$ & 13 & 16.25 \\
\cline { 2 - 4 } & $20-22$ & 61 & 76.25 \\
\cline { 2 - 4 } & $23-25$ & 5 & 6.25 \\
\cline { 2 - 4 } & $26+$ & 1 & 1.25 \\
\cline { 2 - 4 } & Less than 60 & 9 & 11.25 \\
\cline { 2 - 4 } & $60-70$ & 9 & 60 \\
\hline
\end{tabular}

The other part of the data was collected from the 70 participants currently studying in different universities in Europe. The samples in this group were attending to different departments of various universities located in European countries. Concerning gender, there was a balanced distribution, in that 35 females, 34 males and 1 unknown contributed to the present study.

Table 3. Demographic Information of Non-native European Participants (Subjects)

\begin{tabular}{|c|c|c|c|}
\hline & Variables & Number & $\%$ \\
\hline \multirow[t]{2}{*}{ Department } & $\begin{array}{l}\text { Related to English } \\
\text { Studies }\end{array}$ & 28 & 40 \\
\hline & Others & 42 & 60 \\
\hline \multirow{3}{*}{ Gender } & Female & 35 & 50 \\
\hline & Male & 34 & 48.57 \\
\hline & Unknown & 1 & 1.42 \\
\hline \multirow{4}{*}{ Age } & $18-19$ & 2 & 2.85 \\
\hline & $20-22$ & 39 & 55.71 \\
\hline & $23-25$ & 24 & 34.28 \\
\hline & $26+$ & 5 & 7.14 \\
\hline \multirow{8}{*}{ Country } & Poland & 28 & 40 \\
\hline & Hungary & 6 & 8.57 \\
\hline & Italy & 5 & 7.14 \\
\hline & Germany & 4 & 5.71 \\
\hline & Belgium & 4 & 5.71 \\
\hline & Portugal & 3 & 4.28 \\
\hline & Spain & 3 & 4.28 \\
\hline & Others & 17 & 24.28 \\
\hline
\end{tabular}




\subsection{Discourse Completion Task}

DCT was employed to reveal the gratitude strategies used by native and non-native speakers. For the first version, presented in Turkish, eighteen situations similar to the DCT used by Einstein and Bodman in form and content were created and in certain instances, the available items were modified to make the situations more familiar and culture-specific for the TSEFL learners. Following the preparation of data collection instruments, the eighty TSEFL learners were selected and the first version of the modified DCT was distributed to the participants who were asked to respond each situation with the demographic information regarding their genders, ages, classes, and cities added to the DCT task. The second version of the DCT was applied four weeks later and the final data collected through DCTs was obtained from non-native European speakers of English (NNESE); this stage was conducted via e-mail and seventy NNESE responded the DCT specially prepared for them.

\subsection{Data Analysis of DCTs}

Prior to the analysis, each TSEFL participant was allocated a reference code. For instance, P1.1.F represents participant $(\mathrm{P})$, the number of the participant (1), class (1), and gender (female), respectively. The same procedure was applied to the foreign participants, in that, the code FP.1.M was used to refer to foreign participant (FP), the number of the participant (1), and gender (male). Other unnecessary variables such as class were not included into the study and the reference code. Afterwards, each response of the participants was coded based on Cheng's (2005) classification system. The coding system applied for the DCTs comprises eight main units. Each response of the participants, therefore, was allocated a number from 1 to 8 considering the order of strategies. After the responses of TSEFL and NNESE learners were coded based on this taxonomy, the choice and frequency of the gratitude expressions were analyzed. First, the responses of the Turkish speaking EFL learners in both Turkish and English languages and then gratitude expressions used by each group of participants were compared. Third, the frequency distribution of gratitude expressions was calculated to observe the differences with respect to gender.

\subsection{Interviews}

To understand the reasons why the respondents responded the way they did, a semi-structured interview technique was used with 44 TSEFL learners. The participants were selected based on the divergent expressions they used in both DCT tasks. After the examination of DCTs and selection of TSEFL learners, an interview protocol consisting of 5 open ended questions was designed. During the interviews, the participants were given both versions of DCT test with the marked and highlighted divergent responses.

\section{Results}

\subsection{Analysis of DCT forms}

Only one example of DCT comparison with the first item was given for space considerations. The results of the DCT task were summarized in the next section. 


\section{Situation 1:}

It is Friday. You look in your wallet, only to notice that you only have no more than 10 TL. One of your good friends notices this and hears you say, "I have to ask money to my family". Upon that, your friend offers to lend you the money you_need for shopping.

Table 4. The Frequency and Percentages of the Use of Strategies of TSEFLL for the $1^{\text {st }}$ Situation

\begin{tabular}{|c|c|c|c|c|c|c|c|c|c|c|}
\hline & & & & & & nglish I & DCT & & & Total \\
\hline & & & 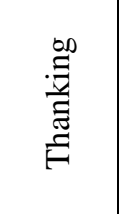 & 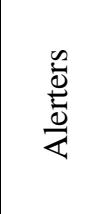 & 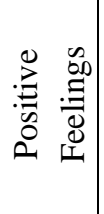 & 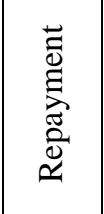 & 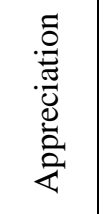 & 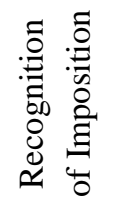 & 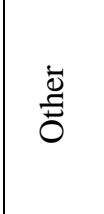 & \\
\hline & & Frequency & 33 & 6 & 2 & 2 & 1 & 7 & 1 & 52 \\
\hline & 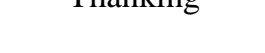 & $\%$ & $41.3 \%$ & $7.5 \%$ & $2.5 \%$ & $2.5 \%$ & $1.3 \%$ & $8.8 \%$ & $1.3 \%$ & $65.0 \%$ \\
\hline & Alertarc & Frequency & 3 & 0 & 0 & 0 & 0 & 2 & 0 & 5 \\
\hline & Alemers & $\%$ & $3.8 \%$ & $0.0 \%$ & $0.0 \%$ & $0.0 \%$ & $0.0 \%$ & $2.5 \%$ & $0.0 \%$ & $6.3 \%$ \\
\hline & Pocitive Eoolinor & Frequency & 1 & 0 & 0 & 0 & 0 & 0 & 0 & 1 \\
\hline ב & Fositive reentings & $\%$ & $1.3 \%$ & $0.0 \%$ & $0.0 \%$ & $0.0 \%$ & $0.0 \%$ & $0.0 \%$ & $0.0 \%$ & $1.3 \%$ \\
\hline$\frac{\sqrt{3}}{3}$ & Annrocintion & Frequency & 1 & 0 & 0 & 0 & $\mathbf{0}$ & 0 & 1 & 2 \\
\hline & Appiectatuon & $\%$ & $1.3 \%$ & $0.0 \%$ & $0.0 \%$ & $0.0 \%$ & $0.0 \%$ & $0.0 \%$ & $1.3 \%$ & $2.5 \%$ \\
\hline & Recognition of & Frequency & 2 & 1 & 1 & 0 & 1 & 6 & 0 & 11 \\
\hline & Imposition & $\%$ & $2.5 \%$ & $1.3 \%$ & $1.3 \%$ & $0.0 \%$ & $1.3 \%$ & $7.5 \%$ & $0.0 \%$ & $13.8 \%$ \\
\hline & Other & Frequency & 7 & 1 & 0 & 0 & 0 & 1 & $\mathbf{0}$ & 9 \\
\hline & Uता & $\%$ & $8.8 \%$ & $1.3 \%$ & $0.0 \%$ & $0.0 \%$ & $0.0 \%$ & $1.3 \%$ & $0.0 \%$ & $11.3 \%$ \\
\hline & Totol & Frequency & 47 & 8 & 3 & 2 & 2 & 16 & 2 & 80 \\
\hline & 10tal & $\%$ & $58.8 \%$ & $10.0 \%$ & $3.8 \%$ & $2.5 \%$ & $2.5 \%$ & $20.0 \%$ & $2.5 \%$ & $100.0 \%$ \\
\hline
\end{tabular}

The responses given to the first situation were demonstrated under six categories in Turkish DCT, and seven in English. The highest occurrence with "thanking", which appeared 52 times in Turkish DCT, is followed by "recognition of imposition" and "other" featuring 11 and 9 times, respectively. The high occurrence of "other" implies the unsuccessful attempts of the participants in expressing their gratitude in Turkish and it is also observed that a small group of participants expressed their gratitude using "alerters". On the other hand, 47 out of 80 Turkish speaking participants applied to "thanking" in English DCT; 16 occurrences of "recognition of imposition" and 8 occurrences of "alerters" emerged. Thus, it is probable to state that TSEFL learners attached more importance to express their gratitude in English, since there is a low frequency of "other" in English DCT. In addition, the responses of 39 participants (33 thanking and 6 recognition of imposition) were the same in both DCTs while 41 TSEFL learners provided divergent gratitude expressions in the two languages. Divergent responses:

\section{In Turkish DCT:}

- The responses of 52 participants applied for "thanking" in Turkish to English DCT: 6 alerters, 2 positive feelings, 2 repayments, 1 appreciation, 7 recognition of imposition and 1 other 
- The responses of 5 participants were "alerters" in Turkish to English DCT: 3 thanking and 2 recognition of imposition

- The response of 1 participant was "positive feelings" in Turkish to English DCT: thanking

- The responses of 2 participants were "appreciation" in Turkish to English DCT: 1 thanking, 1 other

- The responses of 11 participants that applied for "recognition of imposition" in Turkish to English DCT: 2 thanking, 1 alerters, 1 appreciation and 1 positive feelings

- The responses of 9 participants referred "other" in Turkish to English DCT: 7 thanking, 1 alerter, 1 recognition of imposition

Therefore, the chi-square test carried out at significance level of 0.05 to reveal any relation between the responses of the TSEFL learners in Turkish DCT and English DCT resulted in p-value of 0.513. As this p-value is higher than 0.05 , it is concluded that there is not any relation between the responses in Turkish DCT and English DCT.

Table 5. The Frequency and Percentages of the Use of Strategies of NNESE and TSEFLL for the $1^{\text {st }}$ Situation

\begin{tabular}{|c|c|c|c|c|c|c|c|}
\hline & & & \multicolumn{4}{|c|}{ Expressions of Gratitude } & \multirow{2}{*}{ Total } \\
\hline & & & Thanking & Alerters & Recognition of Imposition & Other & \\
\hline \multirow{4}{*}{$\begin{array}{l}\text { Participant } \\
\text { groups }\end{array}$} & \multirow{2}{*}{ NNESE } & Frequency & 29 & 6 & 10 & 25 & 70 \\
\hline & & $\%$ & $41.4 \%$ & $8.6 \%$ & $14.3 \%$ & $35.7 \%$ & $100.0 \%$ \\
\hline & \multirow{2}{*}{ TSEFLL } & Frequency & 47 & 8 & 16 & 9 & 80 \\
\hline & & $\%$ & $58.8 \%$ & $10.0 \%$ & $20.0 \%$ & $11.3 \%$ & $100.0 \%$ \\
\hline \multirow{2}{*}{\multicolumn{2}{|c|}{ Total }} & Frequency & 76 & 14 & 26 & 34 & 150 \\
\hline & & $\%$ & $50.7 \%$ & $9.3 \%$ & $17.3 \%$ & $22.7 \%$ & $100.0 \%$ \\
\hline
\end{tabular}

Table 5 demonstrates that 29 out of 70 NNESE responding to English DCT used "thanking"; 25 of them "other", 10 "recognition of imposition" and 6 "alerters". 47 out of 80 TSEFL learners expressed "thanking"; 16 participants applied to "recognition of imposition", 9 "other" and 8 "alerters". As the pvalue (0.005) discovered following chi-square test is less than 0.05 , it is figured out that there is a relation between the responses of both groups. However, this relation between the two values is weak since the value of the contingency coefficient is 0.281 .

Table 6. Overall Distribution of Gratitude Strategies for the Participant Groups

\begin{tabular}{cccccc}
\hline \multirow{2}{*}{ Expressions of Gratitude } & \multicolumn{3}{c}{ TSEFL learners } & \multicolumn{2}{c}{ NNESE } \\
\cline { 2 - 6 } & $\begin{array}{c}\text { Turkish } \\
\text { Frequency }\end{array}$ & $\begin{array}{c}\text { English } \\
\text { Frequency }\end{array}$ & Percentage & Frequency & Percentage \\
\hline Thanking & 674 & 861 & $59.79 \%$ & 631 & $50.80 \%$ \\
\hline Appreciation & 30 & 25 & $1.73 \%$ & 51 & $4.10 \%$ \\
\hline Positive feelings & 358 & 287 & $19.93 \%$ & 367 & $29.54 \%$ \\
\hline Apology & 6 & 2 & $0.13 \%$ & 4 & $0.32 \%$ \\
\hline
\end{tabular}




\begin{tabular}{cccccc}
\hline Recognition of imposition & 37 & 34 & $2.36 \%$ & 33 & $2.65 \%$ \\
\hline Repayment & 92 & 46 & $3.19 \%$ & 33 & $2.65 \%$ \\
\hline Other & 173 & 95 & $6.59 \%$ & 58 & $4.66 \%$ \\
\hline Alerters & 70 & 90 & $6.25 \%$ & 65 & $5.23 \%$ \\
\hline Total & 1440 & 1440 & $100 \%$ & 1242 & $100 \%$ \\
\hline
\end{tabular}

The distribution of the frequencies of the strategies used by the TSEFL learners in the Turkish and English DCTs revealed that the most frequent three strategies in both DCTs appeared the same. These strategies are "thanking", "positive feelings" and "other", respectively; however, their frequencies varied across languages. The least preferred strategy becomes "apology" not only in Turkish but also in English. Besides, it is found out that the participants produced more "thanking" and "alerters" in English, whereas they resorted to "positive feelings", "repayment", "other" and "alerters" remarkably more in Turkish to express gratitude. This implies that the Turkish speakers referred to expressions like "thank" and "thank you so much" more frequently in English.

Turkish speaking participants employed more "thanking", "alerters", "other" and "repayment" whereas "positive feelings", "appreciation" and "apology" were more frequent among the NNESE. Additionally, the NNESE recognized the imposition they caused on the favor giver more than the TSEFL learners did. The data showed that the TSEFL learners generally applied to simple thanking words rather than supporting it with the expressions reflecting positive feelings to people. They also included names, titles, and attention getters more frequently into their gratitude expressions; however, they experienced difficulties appreciating hearers and further failed to express their gratitude (only 95 times). On the other hand, the NNESE were more successful in their statements to express gratitude since they resulted in fewer "other" (58 times) strategy. For both groups of participants, it was interesting to observe that they barely referred to apologetic words while thanking.

\subsection{Gender-based Comparison}

The responses based on gender were analysed via chi-square test to observe the relation between gender and the responses of the participants.

Table 7. Chi-Square Test Analysis of the Use of Strategies for Gender

\begin{tabular}{ccccc}
\hline Situation & Test Statistics & SD & $\mathbf{p}$ & Result \\
\hline 1 & 13.434 & 1 & .000 & Significant \\
\hline $2-18$ & & & & Insignificant \\
\hline
\end{tabular}

Regarding gender, Table 7 shows that almost all the responses provided by the learners to the DCTs in Turkish and English are different from each other and no statistically significant relations exist among the items. Only one item (question 1) shows statistically meaningful and significant relation between the gender and the use of strategies. Therefore, both genders seem to have given similar categorical responses to this situation (p-value .000).

Table 8. The Gender- Based Distribution of Gratitude Strategies in the Turkish DCT for the TSEFL 


\begin{tabular}{|c|c|c|c|c|}
\hline \multirow{3}{*}{ Expressions of Gratitude } & \multicolumn{4}{|c|}{ Gender } \\
\hline & \multicolumn{2}{|c|}{ Female } & \multicolumn{2}{|c|}{ Male } \\
\hline & Frequency & Percentage & Frequency & Percentage \\
\hline Thanking & 476 & $33.10 \%$ & 198 & $13.80 \%$ \\
\hline Positive feelings & 236 & $16.40 \%$ & 122 & $8.50 \%$ \\
\hline Other & 102 & $7.10 \%$ & 71 & $4.90 \%$ \\
\hline Repayment & 64 & $4.40 \%$ & 28 & $1.90 \%$ \\
\hline Alerters & 43 & $3.00 \%$ & 27 & $1.90 \%$ \\
\hline Recognition of the imposition & 24 & $1.70 \%$ & 13 & $0.90 \%$ \\
\hline Appreciation & 23 & $1.60 \%$ & 7 & $0.50 \%$ \\
\hline Apology & 4 & $0.30 \%$ & 2 & $0.10 \%$ \\
\hline
\end{tabular}

Gender-based choice strategies for both groups are shown in Table 8. While "Thanking" is overwhelmingly the most frequently used strategy among female participants, "thanking" and "positive feelings" are the most common strategies for male subjects, respectively. On the other hand, "apology" emerges as the least referenced strategy in both groups. "Other" seems to become the third most frequent strategy, implying that both males and females were unsuccessful (173) in their attempts to show their gratitude. That is a relatively high frequency regarding the other gratitude strategies falling behind it. The findings further demonstrated the overall distribution of the expressions of gratitude used by the TSEFL learners in Turkish. The chi-square test results display that since $p$-value is higher than 0.05 , and there is no statistically significant relation between the strategies of female and male participants in the Turkish DCT.

Table 9. The Gender- Based Distribution of Gratitude Strategies in the English DCT for the TSEFL Learners

\begin{tabular}{ccccc}
\hline \multirow{2}{*}{ Expressions of Gratitude } & \multicolumn{3}{c}{ Female } & \multicolumn{2}{c}{ Male } \\
\cline { 2 - 5 } & Frequency & Percentage & Frequency & Percentage \\
\cline { 2 - 5 } & 588 & $40.80 \%$ & 273 & $19.00 \%$ \\
\hline Thanking & 220 & $15.30 \%$ & 67 & $4.70 \%$ \\
\hline Positive feelings & 51 & $3.50 \%$ & 39 & $2.70 \%$ \\
\hline Alerters & 47 & $3.30 \%$ & 48 & $3.30 \%$ \\
\hline Other & 30 & $2.10 \%$ & 16 & $1.10 \%$ \\
\hline Repayment & 27 & $1.90 \%$ & 7 & $0.50 \%$ \\
\hline Appreciation & 7 & $0.50 \%$ & 18 & $1.30 \%$ \\
\hline Apology & 2 & $0.10 \%$ & 0 & $0.00 \%$ \\
\hline
\end{tabular}

A close examination of Table 9 reveals that "thanking" is the most popular strategy for both groups of participants in the English DCT, which is followed by "positive feelings". The third most frequent strategy for females is "alerters" and for males is "other". There are also variations related to the frequency of the least employed strategies. The female TSEFL learners include "apology" merely twice to their expressions of gratitude and "recognition of imposition" emerges as the least frequent strategy 
for the male participants. In addition, concerning the frequency of 'other', which is almost equal for both groups, it might be concluded that females are more efficient in responding a favor. Table 9 also indicates that there is no reference for 'apology' in the strategies of the male participants. It further displays the total quantity of the strategies preferred in the English DCT. The chi-square test results revealed that there was statistically significant relationship between the responses of the female and male TSEFL learners as p-value is lower than 0.05 .

Table 10. The Gender- based Distribution of Gratitude Strategies in the English DCT for the NNESE

\begin{tabular}{ccccc}
\hline \multirow{2}{*}{ Expressions of Gratitude } & \multicolumn{3}{c}{ Gender } \\
\cline { 2 - 5 } & \multicolumn{2}{c}{ Female } & Male \\
\cline { 2 - 5 } & Frequency & Percentage & Frequency & Percentage \\
\hline Thanking & 321 & $25.8 \%$ & 310 & $25.0 \%$ \\
\hline Positive feelings & 200 & $16.1 \%$ & 167 & $13.4 \%$ \\
\hline Appreciation & 28 & $2.3 \%$ & 23 & $1.9 \%$ \\
\hline Repayment & 21 & $1.7 \%$ & 12 & $1.0 \%$ \\
\hline Other & 20 & $1.6 \%$ & 38 & $3.1 \%$ \\
\hline Alerters & 19 & $1.5 \%$ & 46 & $3.7 \%$ \\
\hline Recognition of imposition & 19 & $1.5 \%$ & 14 & $1.1 \%$ \\
\hline Apology & 2 & $.2 \%$ & 2 & $.2 \%$ \\
\hline
\end{tabular}

Table 10 illustrates that "thanking" is the most frequently used strategy among both NNESE groups, and female and male frequencies are close to one another. The second popular strategy among the female and male participants is "positive feelings" and it is followed by "appreciation", "repayment" and "other". The males preferred "alerters", "other" and "appreciation" respectively. Table 10 also reveals that the female NNESE produced more 'appreciation', 'repayment' and 'recognition of imposition' strategies to express their gratitude. The chi-square test results, on the other hand, indicates that since pvalue is lower than 0.5 , there is a significant relationship between the responses of the female and male NNESE for the English DCT.

\subsection{Comparison for English Proficiency Levels}

The comparisons of the Turkish and English DCTs for TSEFLL with regard to their English proficiency level is given first. The distribution of the responses given to the DCTs were gathered by comparing the preferred strategies based on grade point averages (GPA). The GPAs' of the two groups of participants ( $1^{\text {st }}$ and $2^{\text {nd }}$ years) were examined for differences. The distribution of types of gratitude strategies based on the responses was displayed for both DCTs separately. Man-Whitney U test was also carried out to observe any statistically significant difference between the responses of the participants who scored higher and the ones with low scores in the exam.

Table 11. Mann-Whitney U Test Analysis of the Strategies for Grades 


\begin{tabular}{|c|c|c|c|c|c|c|}
\hline Situation & Response & Frequency & Grade $\operatorname{Mean} \pm$ SD & $\begin{array}{c}\text { Test Statistics } \\
\text { (Mann- Whitney U) }\end{array}$ & $\mathbf{p}$ & Result \\
\hline \multirow{2}{*}{1} & Same & 39 & $69.74 \pm 1 ., 22$ & \multirow{2}{*}{680.5} & \multirow{2}{*}{0.241} & \multirow{2}{*}{ Insignifican } \\
\hline & Different & 41 & $72.61 \pm 7.78$ & & & \\
\hline \multirow{2}{*}{2} & Same & 47 & $71.30 \pm 10.76$ & \multirow{2}{*}{672} & \multirow{2}{*}{0.301} & \multirow{2}{*}{ Insignificant } \\
\hline & Different & 33 & $71.09 \pm 6.197$ & & & \\
\hline \multirow{2}{*}{3} & Same & 30 & $73.03 \pm 5.41$ & \multirow{2}{*}{617} & \multirow{2}{*}{0.176} & \multirow{2}{*}{ Insignificant } \\
\hline & Different & 50 & $70.12 \pm 10.64$ & & & \\
\hline \multirow{2}{*}{4} & Same & 32 & $72.88 \pm 6.409$ & \multirow{2}{*}{663} & \multirow{2}{*}{0.292} & \multirow{2}{*}{ Insignificant } \\
\hline & Different & 48 & $70.10 \pm 10.46$ & & & \\
\hline \multirow{2}{*}{5} & Same & 28 & $73.32 \pm 4.95$ & \multirow{2}{*}{580.5} & \multirow{2}{*}{0.128} & \multirow{2}{*}{ Insignificant } \\
\hline & Different & 52 & $70.08 \pm 10.58$ & & & \\
\hline \multirow{2}{*}{6} & Same & 55 & $70.24 \pm 10.19$ & \multirow{2}{*}{613.5} & \multirow{2}{*}{0.432} & \multirow{2}{*}{ Insignificant } \\
\hline & Different & 25 & $73.36 \pm 5.71$ & & & \\
\hline \multirow{2}{*}{7} & Same & 35 & $70.20 \pm 11.52$ & \multirow{2}{*}{780.5} & \multirow{2}{*}{0.945} & \\
\hline & Different & 45 & $72.00 \pm 6.71$ & & & Insignificant \\
\hline $\mathbf{0}$ & Same & 41 & $72.05 \pm 10.92$ & 62250 & 0081 & Insionificant \\
\hline $\mathbf{0}$ & Different & 39 & $70.33 \pm 6.75$ & $0<2.50$ & 0.001 & msigmintedit \\
\hline 0 & Same & 34 & $71.97 \pm 6.09$ & 750 & 0010 & Incianifion \\
\hline 9 & Different & 46 & $70.65 \pm 10.85$ & 159 & 0.819 & insigniticant \\
\hline & Same & 48 & $70.23 \pm 10.72$ & & & \\
\hline 10 & Different & 32 & $72.69 \pm 5.78$ & 715.5 & 0.598 & Insignificant \\
\hline 11 & Same & 20 & $71.15 \pm 5.47$ & 536 & 0467 & Insionificant \\
\hline 11 & Different & 60 & $71.23 \pm 10.08$ & 350 & 0.401 & IIsigmitcait \\
\hline 12 & Same & 55 & $70.87 \pm 10.26$ & 687 & 0.06 & \\
\hline 12 & Different & 25 & $71.96 \pm 5.96$ & 681 & 0.96 & Insignificant \\
\hline 12 & Same & 20 & $68.15 \pm 13.07$ & 507 & 0.407 & \\
\hline 13 & Different & 60 & $72.23 \pm 7.21$ & 321 & 0.401 & Insignificant \\
\hline & Same & 40 & $70.55 \pm 7.5$ & & & Insionificant \\
\hline 14 & Different & 40 & $71.88 \pm 10.53$ & 630.5 & 0.095 & Insignificant \\
\hline 15 & Same & 29 & $71.07 \pm 6.61$ & 626 & 0280 & Incionificont \\
\hline 15 & Different & 51 & $71.29 \pm 10.33$ & 030 & 0.289 & Insigniticant \\
\hline & Same & 49 & $70.84 \pm 7.91$ & 6545 & 0289 & Insionificant \\
\hline 16 & Different & 31 & $71.81 \pm 10.86$ & 654.5 & 0.289 & Insigniticant \\
\hline & Same & 59 & $69.95 \pm 9.62$ & & 0017 & \\
\hline 17 & Different & 21 & $74.76 \pm 6.45$ & 406.5 & 0.017 & Significant \\
\hline 18 & Same & 38 & $70.00 \pm 8.28$ & 600 & 063 & Incignificant \\
\hline 10 & Different & 42 & $72.31 \pm 9.77$ & 609 & 0.63 & ificant \\
\hline
\end{tabular}


For the first question, the GPA of 39 participants responding with the same strategy to the Turkish and English DCTs is 69.74; on the other hand, the GPA of 41 participants using different strategies in both DCTs is 72.61 . The comparison of the grades that belong to the participants providing same and different responses results in the value of relation 0.241, which is higher than 0.05 . $(p=0.241>0.05)$. Therefore, it is concluded that this value is meaningless, and there is not any statistically significant difference between the participants related to their grades. However, "requesting someone to open a door" yielded to meaningful results, since p-value appears as $0.017(\mathrm{p}=0.017<0.05)$. Hence, the situation responded through the same strategies in both DCTs by 59 participants and different strategies by 21 participants, displays statistically significant differences in respect of GPAs of the two groups.

In general terms, it appears that as the GPAs of the participants slightly differ, any statistically significant difference does not occur. Therefore, we found no significant influence on their responses in expressing gratitude. In addition, Table 13 below shows the general distribution of the strategies performed by the TSEFL learners in Turkish DCT with respect to the grades with minimum and maximum values. It revealed that 80 participants used totally of 1440 strategies to express their gratitude for 18 situations. "Thanking" seems to happen the most widely distributed strategy, and "positive feelings" is the second frequent type for the participants having grades from 20 to 84 . "Other" which indeed does not include gratitude expressions, emerges as the third strategy; that implies 173 times unsuccessful attempts to show gratitude for the favors. This is followed by 'repayment' (92), "alerters" (70), and "recognition of imposition" (37). "Appreciation" (30) appears as the least preferred strategy for the participants their range of grades change between 20 and 84. "Apology" (6) seems to be performed merely by the participants with grades 58 to 81 .

Table 13. The Frequency of the Types of Strategies for the Turkish DCT Based on Grades

\begin{tabular}{lccccc}
\hline \multirow{2}{*}{ Expressions of Gratitude } & Frequency & Mean & Grades & Minimum & Maximum \\
\hline Thanking & 674 & 70.89 & 8.937 & 20 & 84 \\
\hline Positive feelings & 358 & 71.95 & 8.552 & 20 & 84 \\
\hline Other & 173 & 71.01 & 8.695 & 20 & 84 \\
\hline Repayment & 92 & 71.42 & 9.187 & 20 & 84 \\
\hline Alerters & 70 & 71.31 & 9.433 & 20 & 84 \\
\hline Recognition of imposition & 37 & 70.73 & 11.364 & 20 & 84 \\
\hline Appreciation & 30 & 70.33 & 14.549 & 20 & 84 \\
\hline Apology & 6 & 71.50 & 8.385 & 58 & 81 \\
\hline Total & 1440 & 71.21 & 9.061 & 20 & 84 \\
\hline
\end{tabular}

All the values indicated that first seven types of gratitude strategies occurring in the gratitude expressions of the TSEFL learners had wider range of grades. On the other hand, the "apology" strategy emerged on a narrower scale. Graphic 1 below also displays the distributions of each thanking strategy regarding the mean scores. 
Scores

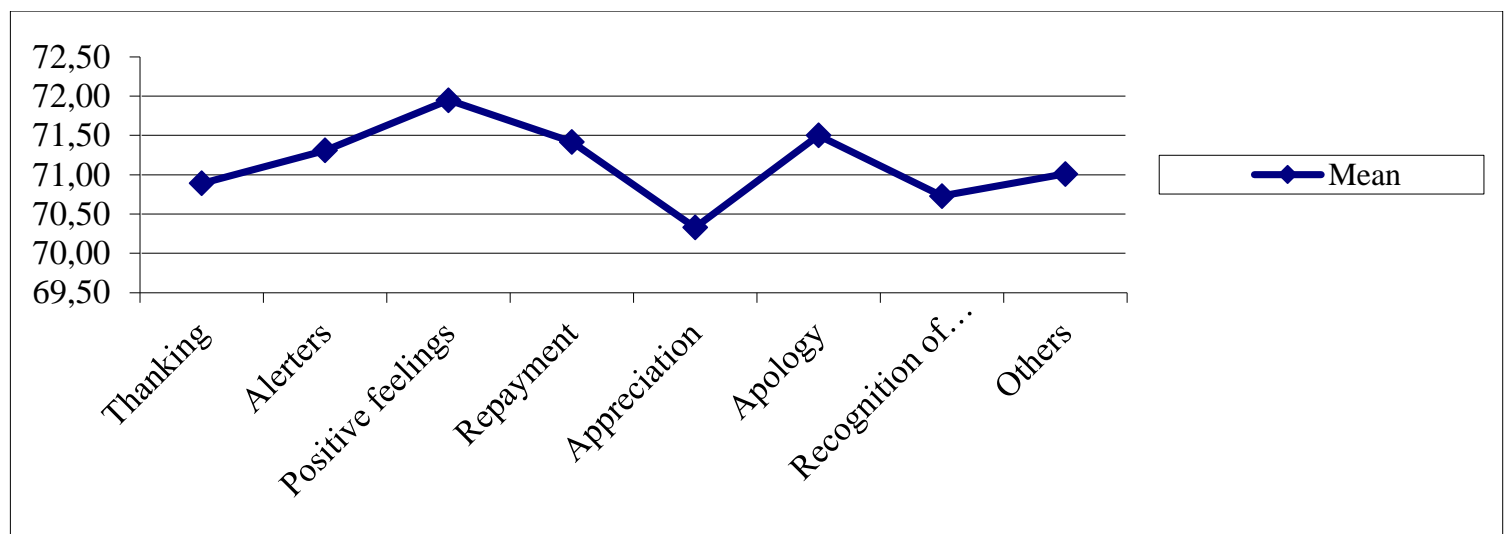

Figure 1. Distribution of the Types of Strategies for the Turkish DCT Based on Mean

The graphic illustrates that TSEFL learners possessing the highest mean score express "positive feeling" while showing their gratitude. Whereas the participants with the lowest mean score apply to "appreciation" expressions. Additionally, "alerters", "repayment" and "apology" expressions are favored by the participants whose mean scores are over 71 .

Table 14. The Frequency of the Types of Strategies for the English DCT Based on Grades

\begin{tabular}{|c|c|c|c|c|c|}
\hline \multirow{2}{*}{ Expressions of Gratitude } & \multicolumn{5}{|c|}{ Grades } \\
\hline & Frequency & Mean & Standart Deviation & Minimum & Maximum \\
\hline Thanking & 861 & 70.25 & 9.915 & & \\
\hline Positive feelings & 287 & 72.49 & 8.421 & 20 & 84 \\
\hline Other & 95 & 73.00 & 6.095 & 50 & 83 \\
\hline Alerters & 90 & 72.53 & 6.097 & 58 & 84 \\
\hline Repayment & 46 & 72.09 & 6.669 & 58 & 84 \\
\hline Recognition of imposition & 34 & 73.21 & 6.577 & 50 & 83 \\
\hline Appreciation & 25 & 73.84 & 6.517 & 63 & 84 \\
\hline Apology & 2 & 70.00 & 0.000 & 70 & 70 \\
\hline Total & 1440 & 71.21 & 9.061 & 20 & 84 \\
\hline
\end{tabular}

Table 14 shows that the most frequently employed strategy is "thanking" with a frequency of 861 , and it is followed by "positive feelings" (287). However, "apology" was preferred only twice. The participants whose scores change between 58 and 84 apply to "alerters" 90 times and "repayment" 46 times. "Appreciation" strategy is preferred 25 times with the highest mean score by the TSEFL learners. 


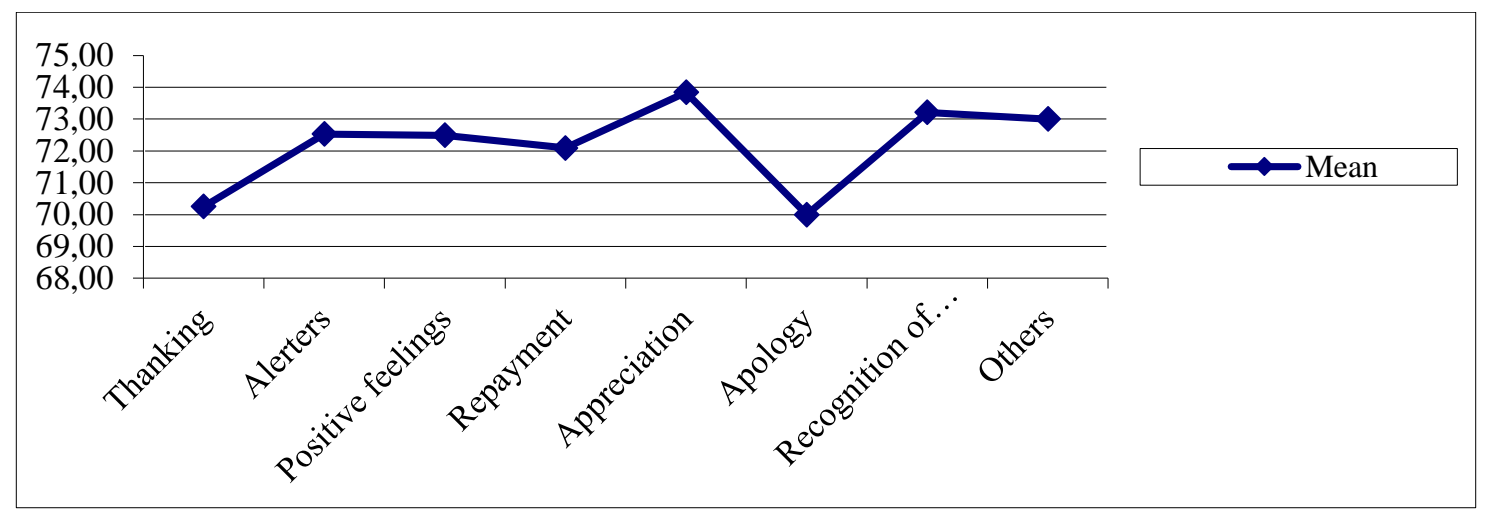

Figure 2. Mean Scores of Strategies for the English DCT

Graphic 2 shows that the participants with the highest mean scores (73 and over) seem to appreciate the favor they receive, they are aware of the imposition on the hearer, and also use expressions lacking gratitude, while the TSEFL learners having the lowest mean score (70) use 'apology' strategies most frequently. 'Thanking' is the common strategy for the participants the mean score belonging to their grades is between 70 and 71 . 'Other' strategies employed fall into the range of which mean values vary between 72 and 73 .

\subsection{Interview Results}

For space considerations, we have presented only the overall interview analysis results in this part. The interview included the following questions.

1. Reasons for the variations in the responses to the situations between Turkish and English?

2. Reasons for shorter answers in English?

3. Why did you reply to the situation in Turkish DCT the way you did?

4. Why did you reply to the situation in English DCT the way you did?

5. Reasons for the different answers to given situations in English?

Overall analyses of the data gathered through interviews (Table 15) demonstrated that "lack of English proficiency" with a total frequency of 103 was the most frequent item, which was followed by "cultural differences" and "low pragmatic competence". Additionally, "satisfactory response" and "preference for short answers" were the other frequent reasons.

Table 15. Outstanding Reasons in the Interview

\begin{tabular}{cccc}
\hline Codes & Freq. & $\%$ & Questions \\
\hline 1. Lack of English proficiency /Lower proficiency in English & 103 & 33 & $1-2-4-5$ \\
\hline 2. Cultural differences /No culture competency / Cultural familiarity & 36 & 12 & $1-2-3-4-5$ \\
\hline 3. Low pragmatic competence & 34 & 11 & $4-5$ \\
\hline 4. Satisfactory response & 30 & 10 & $3-4-5$ \\
\hline 5. Preference for short answers & 26 & 8 & $1-2-4$ \\
\hline 6. No equivalency between Turkish- English/ English equivalency & 19 & 6 & $1-2-3-4$ \\
\hline
\end{tabular}




\begin{tabular}{|c|c|c|c|c|}
\hline & 7. Deserves better repayment / Repayment & 10 & 3 & $3-4$ \\
\hline \multicolumn{2}{|r|}{ 8. Pragmatic choice of expressions } & 9 & 3 & $3-4$ \\
\hline \multicolumn{2}{|r|}{ 9. Linguistic differences } & 7 & 2 & 1 \\
\hline \multicolumn{2}{|r|}{$\begin{array}{l}\text { Higher proficiency in English, Habitual behavior, Daily } \\
\text { expression. Difference in opinion, Fixed expressions in } \\
\text { English, Formal English education, Preference to give polite } \\
\text { answers, Better expressions in Turkish, Mother tongue, Need } \\
\text { for longer expressions, I don't care, Common usage, Reduced } \\
\text { face threat, Different types of expressions, Preference for } \\
\text { familiar expressions, Simple expressions in English }\end{array}$} & 38 & 12 & $1-2-3-4-5$ \\
\hline \multicolumn{2}{|r|}{ Total } & 312 & 100 & $1-2-3-4-5$ \\
\hline
\end{tabular}

The encoded categories for the interview questions were given in Table 15 with their percentages and frequencies. The most effective factor for the variations seemed to be "the lack of English proficiency" (103) and is followed by "cultural differences" (36) and "low pragmatic competence" (34). The first three categories constitute more than half of the all responses (56\%) alone and seem to be most important factors behind the variations. They are followed by "satisfactory response" and "preference for short answers".

Since "the lack of English proficiency" was the most frequent response to the first question, it was necessary to interpret this finding carefully. The responses variations between the two DCTs may be due to the fact that Turkish learners were inadequate in responding to the favour in English. There is evidence in the interviewees' responses to support this finding. Several participants commented on their language proficiency levels as the following:

P.1.1.F: "One of the main reasons is that since Turkish is my mother tongue, it is easier to express myself. Because I do not know how to convey the same meaning in English, I have tried to express myself in simpler ways."

P.1.2.M: "As I think my English proficiency level is insufficient, I may have been expressed myself in my mother tongue in a more comfortable way."

P.4.1.F. "I still think that this is because of the reasons I stated above. Since I do not have much vocabulary and structural knowledge, I generally try to use expressions that could give the closest meaning to the Turkish version while using English".

P.9.2.F: "It could be because I do not know the English equivalents of the same sentences".

P.15.1.M. "Because I do not have a good command of English."

P.24.2.F: "Because I cannot use English as efficiently and fluently as I can in my mother tongue. Although I have been learning English for years, it is difficult to express yourself in English" 
P.38.2.F: "I had difficulty in expressing gratitude in English in general. I was not sure about what kind of an expression I needed to use exactly".

The participants found their English proficiencies were lacking in some respects, which is surprising considering the fact that these students were given a central exam based on mainly English proficiency and they additionally received English courses in the preparatory classes of the university for one or two terms. It is also surprising to observe that more than a quarter of the reasons given by the interviewees were 'short and less complex' responses.

Since "cultural differences" is the second most prevalent response among the interviewees, several statements supporting it were given below.

P.4.1.F: “ First of all, I think that this is because of cultural and linguistic differences. For example, we express Ramazan Feast, which is in Turkish, in a way that people from another culture could understand since it is not available in another culture."

P.6.2.F.: "I thought that the expression "Thank you sir" would be enough at that time...".

P.22.2.M: “Cultural reasons' and 'lack of proficiency”

P.23.1.F: "I think that the first reason is cultural differences. I am not competent enough to give that kind of responses in the other culture."

P.35.1.M: "Main reason is that they are languages belonging to two distinct cultures and a word-for-word translation is not always correct."

P.40.2.F: "There are many words in Turkish that could be replaced with the word "gratitude" or sharing the same meaning; in English, however, I thought that the expression "thank you" would be enough. It did not come to my mind then that there could be or there is a word that fully corresponds with the word "Gratitude" in their culture."

One of the participants, on the other hand, implied that her pragmatic competency related to English is low and others that they preferred "short answers" and there was "inequality between the languages".

P.21.1.F.: "As I generally did not encounter the written situations in English, I could not know what I could write."

P.14.1.F: "As I wanted to express my feelings and thoughts in a proper way, I preferred it to be short and sweet".

P.16.2.F: "I did not want to make it complicated making up long sentences."

P.21.1.F: "Because I did not know how to reply, I wrote "thanks" and "thank you" taking the easy way out. Any expressions of gratitude did not come to my mind. I could not know what I would be able to write as I generally did not come across the situations written as English."

P.24.1.M: "I did not think that I needed to express more, I responded shortly. 
P.35.1.M: "The most frequent expression I used is "thank you", which is the greatest response to give for almost all situations. Short and sweet."

P.40.2.F: $\quad$ "I gave short responses as I thought it was enough."

P.18.2.F: "Our language is inadequate"

P.13.2.F: "There are not exact equivalents of some patterns and phrases in English".

"Deserves better repayment" was also among the responses, suggesting that some participants seemed to show evidence that they were aware of the constituent parts of pragmatics and adjusted their manner and expressions to varying conditions of gratitude contexts such as age, position, intimacy, and so on.

P.40.1.M: "I gave such a response, because I wanted to express that I was so grateful for that situation."

P.26.2.F.: "Because I thought that the interlocutor deserved such a response. As I felt like that way, I wrote that".

P.21.1.F: "Because of the ... with the person I talked...".

P.38.1.F: "My way of addressing changes according to interlocutors."

These factors revealed that TSEFL learners' divergent responses to both tasks were due to the fact that they do not feel they are competent neither in English nor with the exact expressions of gratitude. The probable reasons behind this factor could be the formal English education focusing on competence rather than performance. Another response was "low pragmatic competence". TSEFL learners appeared to feel no certainty about expressing their gratitude in changing discourses with different interlocutors. It seemed that they are generally not able to adjust their language use to the contexts. This also implies that even though the participants learning English for at least nine years through formal education, they may not be competent enough in spoken English and pragmatic expressions. Yet another frequently stated reason was "cultural differences"; TSEFL learners claimed that it is challenging to find English equivalents of some Turkish terms and expressions especially related to religion. Considering the strong relation between language and culture, the challenges TSEFL learners experienced imply cultural incompetency with respect to the target language.

\section{Discussion}

We found that the findings of the first question showed that the preferences for expressions of gratitude are not consistent in both languages; that is, the participants performed different thanking strategies to respond to the same situations in Turkish and English. The chi-square results further supported that the responses of the TSEFL learners were divergent substantially. The strategies used in situations $2,5,6,13,14,15$, and 18 , on the other hand, seemed to occur in relevancy though the level of significance was quite low and these findings were insignificant for the research. Moreover, it appeared that TSEFL learners mostly resorted to "thanking" and "positive feelings" strategies in both languages, respectively. Yet, the variety of the strategies given to each situation was higher in their first language. It is also revealed that Turkish speakers rarely referred to apologetic words in their expressions of gratitude and there were more unacceptable responses in Turkish compared to English. Yet, the 
quantity of the problematic responses in English was still relatively high considering the target participants. This finding may be concurrent with the Eisenstein and Bodman's (1993) views that "Even advanced learners of English have considerable difficulty adequately expressing gratitude" (p. 75). The findings we obtained for the second question, related to the comparison of TSEFL learners with NNESE, indicated that Turkish speakers and European speakers diverged in their expressions of gratitude for the same situations despite the fact that "thanking" emerged as the most preferred strategy among two groups of participants. "Positive feelings", on the other hand, was the second widely used strategy for both groups. With this in mind, however, we observed that Turkish speakers tended to prefer simple thanking rather than expressing positive statements to their favor giver, whereas European speakers seemed somewhat compelled to make their interlocutors feel more positive in return of a favor. The findings also showed that there were more unsuccessful attempts of Turkish speakers in performing gratitude strategies or they were not aware of suitable gratitude expressions to the situations. The results implied the evidence of cross-cultural differences on the preferences of gratitude strategies and language uses. Additionally, the reason behind the variations and divergences may be due to the incompetency of Turkish speakers in English since this factor was mentioned predominantly during the interviews. Regarding the question on gender difference, we have seen that the thanking strategies employed by Turkish female and male participants showed variations. They produced relevant gratitude expressions to merely one situation in which they thanked for a "loan or an offer to give loan" and yet, in the other situations they seemed to have significantly varied; therefore, it seemed that there was no statistically significant relation between the groups and the frequency order of the gratitude strategies was the same for both female and male participants. "Thanking", however, was overwhelmingly the most frequent strategy among the females though the males included pleasing expressions besides thanking words for showing their gratitude in Turkish. The participants were also inefficient in expressing gratitude in many occasions in their mother tongue since "others" appeared as the third common strategy. There are various reasons for these problematic responses with the "lack of pragmatic competence" as the main factor. Moreover, in English both the females and the males mostly preferred thanking words and positive feelings respectively, yet the females seemed to have expressed their gratitude more successfully than the males. The female and male European participants' most popular two strategies were not different from those of Turkish speakers and the males produced almost an equal number of irrelevant expressions similar to the Turkish male participants. Our analysis for the fourth question indicated an increase in the proficiency level of the learners with almost no improvement in the realization of thanking. This finding, however, may not ensure reliable inferences, as the proficiency levels of the participants were not considerably significant. The participants from all grades employed almost all strategies in Turkish except for "apology" performed only by the participants having relatively better scores. On the other hand, every Turkish participant applied to 'thanking' and 'positive feelings' strategies to express their gratitude in English, yet only those with the highest grades in English were able to appreciate the favor they received.

Han and Tanrı̈ver (2015. p. 522) stated that "EFL learners in Turkey may face several difficulties in using English in a variety of contexts due to the factors associated with pragmatic and linguistic competence". The participants of the study similarly reported "lack of English proficiency" and "low pragmatic competence" as the leading factors underlying their divergent or unsuccessful performances while expressing their gratitude. Based on another frequently given factor, it is probable to claim that the participants do not have a good command of target language culture as they were not able to adjust their languages into various situations. One of the main difficulties that the Turkish speakers faced during this period seemed to be their attempts to transfer the specific constituents of their mother tongue and culture into target language without actually considering the norms and specific culture carefully enough. Contrary to these factors, there were participants consciously preferring short answers in their 
expressions like "thank" and "thank you", considering that the responses would be enough for the given situations.

\section{Conclusions}

\subsection{Implications}

The present study offers several pedagogical implications for syllabus designers and instruction. First, course materials should be designed paying attention to the needs of language learners, specifically the potential speech acts that these learners may face in a target language must be included. The materials should present various situations in which each type of expression is presented through native speaker norms. Second, the main contact of foreign language learners with a target language occurs in the classroom environment with the limited communication opportunities. Therefore, learners should be exposed to more authentic target language and materials so that they are able to tell the differences with the usage patterns for cross-cultural deviations. In addition, more activities should be planned to provide more opportunities for learners to develop strategies to use authentic language and target speech acts. Concerning the findings of the study, Turkish EFL learners should be aware of divergent and similar aspects of Turkish and English with respect to the expressions of gratitude strategies to be performed in various situations within the two cultures.

\section{Ethics Committee Approval}

The authors confirm that this study does not need ethics committee approval. (Date of Confirmation: 12.05.2020)

\section{Acknowledgements}

This paper is based on the MA Thesis of the first author.

\section{References}

Ahn, S.J. (2007). Korean ESL learners' pragmatic competence: Motivation, amount of contact, and length of residence (Unpublished doctoral dissertation). Texas A\&M University, United States of America.

Araz, A. \& Erdugan, C. (2017). Developing a scale for measuring the expression of gratitude. Nesne Psikoloji Dergisi, 5(11), 404-425.

Bardovi-Harlig, K. (1996). Pragmatics and language teaching: Bringing pragmatics and pedagogy together. In L. F. Bouton (Ed.), Pragmatics and Language Learning (pp. 21-39).

Bardovi-Harlig, K. (1999). Exploring the interlanguage of interlanguage pragmatics: A research agenda for acquisitional pragmatic. Language Learning, 49(4), 677-713.

Bialystok, E. (1993). Symbolic representation and attentional control in pragmatic competence. In G. Kasper \& S. Blum-Kulka (Eds.), Interlanguage pragmatics (pp. 43-59). Oxford University Press. New York. 
Bodman, J. \& Eisenstein, E. M. (1988). May God increase your bounty: The expressions of gratitude in English by native and non-native speakers. Cross Currents, 15(1), 1-21.

Brown, P. \& Levinson, S. C. (1987). Politeness: Some universals in language usage. Cambridge University Press. Cambridge.

Buján Sánchez, L. (2016). Pragmatic competence in Spanish students of EFL: Making requests and apologies (Unpublished master dissertation). University of A Coruña, Spain.

Chang, C.Y. (2008). An interlanguage study of Chinese EFL students' expression of gratitude (Unpublished master dissertation). National Sun Yat-Sen University:Guangzhou, China.

Cheng, S. W. (2005). An exploratory cross-sectional study of interlanguage pragmatic development of expressions of gratitude by Chinese learners of English (Unpublished doctoral dissertation). The University of Iowa, United States of America.

Coulmas, F. (1981). 'Poison to your soul': Thanks and apologies contrastively viewed. In F. Coulmas (Ed.), Conversational routine (pp. 69-91). Mouton: Hague.

Dogancay-Aktuna, S. \& Kamisli, S. (1997). Pragmatic transfer in interlanguage development: A case study of advanced EFL learners. Retrieved from https: //files.eric.ed.gov (29.09.2018)

Eisenstein, M. \& Bodman, J. (1986). I very appreciate: Expressions of gratitude by native and nonnative speakers of American English. Applied Linguistics, 7(2), 167-432.

Eisenstein, M. \& Bodman, J. (1993). Expressing gratitude in American English. In G. Kasper and S. Blum-Kulka (Eds.), Interlanguage pragmatics (pp. 64-81). Oxford University Press. New York.

Elwood, K. (2010). An analysis of expressing gratitude in Irish English and New Zealand English. Cultural Theory, 36, 110-153.

Falasi, H. A. (2007). Just say 'thank you': A study of compliment responses. The Linguistic Journal, $2(1), 28-42$.

Farnia, M. \& Suleiman, R. (2009). An interlanguage pragmatic study of expressions of gratitude by Iranian EFL learners - A pilot study. Malaysian Journal of ELT Research, 5, 108-140.

Han, T. \& Tanriöver, A. S. (2015). The factors that affect pragmatic competence and Turkish EFL research context. International Journal of Arts \& Sciences, 8(7), 515-523.

Hymes, D. (1972). On communicative competence. In J. B. Pride \& J. Holmes (Eds.), Sociolinguistics (pp. 269-293). London: Penguin.

Intachakra, S. (2004). Contrastive pragmatics and language teaching: Apologies and thanks in English and Thai, RELC, 35(1), 37-62.

Karatepe, Ç. (2001). Pragmalinguistic awareness in EFL teacher training. Language Awareness, 10(23), 178-188.

Kashdan, Tod B. et al. (2009). Gender differences in gratitude: Examining appraisals, narratives, the willingness to express emotions, and changes in psychological needs. Journal of Personality, 77(3), 691-730.

Kasper, G. (1992). Pragmatic transfer. Second Language Research, 8(3), 203-231.

Lamb, C. (2005). Misunderstandings - A sociolinguistic view on meaning. Letras de Hoje, 40(1), 231241. 
Li, Rui et al. (2015). An investigation into Chinese EFL learners' pragmatic competence. GEMA Online ${ }^{\circledR}$ Journal of Language Studies, 15(2), 101-118.

Meiramova, S. \& Kulzhanova, A. (2015). The peculiarities of gratitude expression use in the foreign language (on the example of English). Open Journal of Social Sciences, 3(6), 15-20.

Özdemir, Ç. \& Rezvani, S. A. (2010). Interlanguage pragmatics in action: Use of expressions of gratitude. Procedia Social and Behavioral Sciences, 3, 194-202.

Pishghadam, R. \& Zarei, S. (2011). Expressions of gratitude: A case of EFL learners. Review of European Studies, 3(2), 140-149.

Searle, J. R. (1969). Speech acts: An essay in the philosophy of language. Cambridge University Press. Cambridge.

Takkaç Tulgar, A. (2016). The role of pragmatic competence in foreign language education. Turkish Online Journal of English Language Teaching (TOJELT), 1(1), 10-19.

Thomas, J. (1983). Cross-cultural pragmatic failure. Applied Linguistics, 4(2), 91-112.

Wang, X. \& Choe, M.-H. (2015). Pragmatic development in expressing gratitude by Chinese and Korean learners of English as a foreign language. The Journal of Humanities, 41, 119-148.

Wolfson, N. (1989). The social dynamics of native and non-native variation in complimenting. In M. R. Eisenstein (Ed.), The dynamic interlanguage (pp. 219-236). Boston: Springer.

\section{İngilizceyi yabancı dil olarak öğrenenlerin minnet ifade etme stratejilerinin araştırılması: Dillerarası edimbilim}

\section{$\ddot{\mathbf{O} z}$}

Türkçe konuşup İngilizceyi yabancı dil olarak öğrenenlerin minnet ifade etme stratejilerini ve şayet varsa minnet ifadelerindeki pragmatik aktarımlarını anlamak dil araştırmacılarının ilgi duyduğu konular arasındadır. Bu amaç için Eisenstein ve Bodman (1986) tarafından oluşturulmuş orijinal hali temel alınarak tasarlanmış ve üniversite birinci ve ikinci sınıfta olup İngilizceyi yabancı dil olarak öğrenen 80 kişi ve yine 70 adet ana dili İngilizce olmayan Avrupalı konuşmacı tarafından tamamlanan üç adet söylem tamamlama görevi, çalışmanın örnekleri olarak alınmıştır. Ayrıca, söylem tamamlama görevine de katılmış Türkçe konuşan 44 katılımcı yoluyla söylem tamamlama görevlerinin sonuçlarını daha iyi anlamak için mülakat verisi derlenmiştir. Araştırma hem nicel hem de nitel veri içermektedir. Söylem tamamlama görevleri ile toplanan nicel veri SPSS programı ile analiz edilmiş ve mülakatlardan gelen nitel veri içerik analizi ile incelenmiştir. Bulgular sadece araştırma grupları arasındaki değil aynı zamanda Türkçe konuşan katılımcıların Türkçe ve İngilizcedeki minnet ifade etme stratejilerini seçim ve sıklıklarına dair cevapların farlılık ve benzerliklerini göstermiştir. Sonuçlar, Türkçe konuşup üniversite düzeyinde İngilizceyi yabancı dil olarak öğrenenlerin ana dili İngilizce olmayan Avrupalı konuşmacılarla karşılaştıııldığında farklı bir tavırda teşekkür söz eylemine başvurduklarını da göstermiştir. Bir başka bulgu Türkçe konuşup İngilizceyi yabancı dil olarak öğrenenlerin, İngilizce yeterliliklerindeki eksiklikten dolayı teşekkür etme stratejilerinde farklılaşmaları olmuştur.

Anahtar kelimeler: Minnet; teşekkür etme söz eylemi; teşekkür etme stratejileri 


\section{AUTHOR BIODATA}

Ali Şükrü ÖZBAY is an Assistant Professor in Karadeniz Technical University. He holds his MA from KTU, Applied Linguistics Program and Ph.D. from the English Language and Literature department of KTU. His main areas of interest include Corpus Linguistics and Learner Corpora, English Phraseology, Sociolinguistics, Academic Writing and Lexicology

Derya BAKIRCI holds an MA degree in Applied Linguistics from Karadeniz Technical University. With her being mainly interested in corpus linguistics and sociolinguistics, she carries out studies in language learning, corpus linguistics, classroom discourse and learner motivation. 